\title{
Seasonal Variation of Tannin and Nutrient in Aegiceras corniculatum Leaves in Zhangjiang Mangrove Ecosystem
}

\author{
Minshen Huang ${ }^{1}$, Lihua Zhang ${ }^{3}$, Shudong Wei ${ }^{*}{ }^{1,2}$, Qi Zeng ${ }^{1}$, Haichao Zhou ${ }^{1}$ and Yiming Lin ${ }^{1}$ \\ ${ }^{I}$ Key Laboratory of the Ministry of Education for Coastal and Wetland Ecosystems, School of Life Sciences, Xiamen \\ University, Xiamen 361005, China \\ ${ }^{2}$ College of Life Sciences, Yangtze University, Jingzhou 434025, China \\ ${ }^{3}$ Key Laboratory of Coastal Environmental Processes and Ecological Remediation, Yantai Institute of Coastal Zone \\ Research (YIC), Chinese Academy of Sciences (CAS); Shandong Provincial Key Laboratory of Coastal Environmental \\ Processes, YICCAS, Yantai 264003, China
}

\begin{abstract}
Seasonal dynamics of total phenolics (TP), extractable condensed tannins (ECT), protein-bound condensed tannins (PBCT), fiber-bound condensed tannins (FBCT), total condensed tannins (TCT) and nitrogen contents in sun and shade leaves of Aegiceras corniculatum were studied in the Zhangjiang Estuary, Fujian Province, China. The contents of TP, ECT and TCT in the sun leaves were significantly higher than those in the shade leaves through the season. The N content in sun leaves was higher than that in shade leaves in the autumn, while it was lower in the summer, and there was no significant difference in the winter and spring. With the respect to the $\mathrm{P}$ through the year, $\mathrm{P}$ content in the sun leaves was different between seasons, with the highest in winter and the lowest in summer. In addition, the TP:N and ECT:N ratios in sun leaves were significantly higher than those in shade leaves except in autumn. High tannin levels and TP:N and ECT:N ratios in the sun leaves not only can reduce oxidative stress, but also improve the ability of resisting plant diseases and insect pests.
\end{abstract}

Keywords: Aegiceras corniculatum, nitrogen, phosphorus, tannins.

\section{INTRODUCTION}

Tannins, a group of phenolic compounds, are a significant component of plant secondary metabolites [1]. They are the fourth most abundant biochemical substance in vascular plant tissue and could be found in plant leaves, roots, wood, bark, fruits and buds [2,3]. Although the synthesis of tannins which has complex structure needs large amount of energy, their widespread occurrence indicated the important role in plant function and evolution $[4,5]$. It has been suggested that dominant plant in poor-nutrient ecosystems exhibited advantages over the other species by the production of large amount of tannins and some other carbon-based secondary compounds [6].

Mangrove ecosystem are known as highly productive ecosystems in the subtropical and tropical coastlines [7-9]. Mangrove was considered to be an important link between terrestrial and marine ecosystems and provide energy base for the adjacent food web [8]. In mangrove species, the concentration of tannins could reach as high as $20 \%$ of the dry weight in the leaf $[1,2]$. This abundant component could prevent the loss of biomass of mangrove from the herbivores and influence the community of intertidal meiofauna in tropical estuaries [10]. Although a lot of studies were carried

*Address correspondence to this author at the Key Laboratory of the Ministry of Education for Coastal and Wetland Ecosystems, School of Life Sciences, Xiamen University, Xiamen 361005, China;

Tel: (86) 0592-5182655; Fax: (86) 0592-5182678;

E-mail: weishudong2005@126.com out on the physiological basis and ecological consequences of leaf tannins, only a few focused on the variability leaf tannins related to environmental changes and developmental stages [1, 11]. The variability not only increased the susceptibility of plants against herbivores, but also is important factor determining the nutrient cycling in terrestrial and aquatic ecosystems [12-14].

Previous studies showed that the tannin content of leaf in mangrove species (Aegiceras corniculatum) decreased with the age and decay stage $[1,15]$. However, the environmental factor, especially the light, played important role in regulating the physiological metabolism. The content and structure of tannins also could be impacted by the light. For example, Treutte (2005) [16] found that light intensity might determine the formation and accumulation of plant secondary metabolites such as tannin. On the other hand, it has been proved that nutrient availability, especially $\mathrm{N}$ and $\mathrm{P}$, is an important factor impacting mangrove growth [1719]. Plant N:P ratio is a useful index in ecological research because it reflects the gradual and dynamic character of nutrient limitation rather than the fixed characters such as $\mathrm{N}-$ limited vs P-limited [20, 21].

The objective of the present study was to test the following hypotheses: (1) Tannins in sun and shade leaves follow a seasonal pattern; (2) The production of phenolics dominates under nutrient limitation. Here we test the above hypothesis by examining the dynamics of tannin and nitrogen in a cryptoviviparous mangrove species (Aegiceras corniculatum) in a subtropical Coastline of China. 


\section{MATERIALS AND METHODS}

\subsection{Study Areas}

The study was conducted in the estuary of Zhangjiang

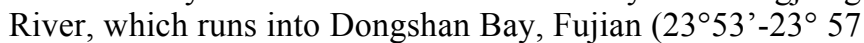
'N , $117^{\circ} 24^{\prime}-117^{\circ} 30^{\prime}$ E). The climate of the region belongs to southern subtropical maritime monsoon climate, with annual temperature ranging from $13.5{ }^{\circ} \mathrm{C}$ to $28.9{ }^{\circ} \mathrm{C}$. Mean annual precipitation and evaporation are $1714.5 \mathrm{~mm}$ and 2027.9 $\mathrm{mm}$, respectively. The salinity of seawater was between 12 and 26 PSU. The soil was clay with salinity above 10 PSU, and the content of organicmatterwas above $2.5 \%$. In this study site, Aegiceras corniculatum was the dominant species with a few Kandelia obvata and Avicennia marina. The mean height of $A$. corniculatum plants was $1.5 \mathrm{~m}$. The $A$. corniculatum forest in Zhangjiang Estuary belongs to the northernmost naturally distributed mangroves in China.

\subsection{Materials}

Thirty individuals of A. corniculatum similar in height and growth conditions were chosen and labeled. Shade and sun leaves from the same shoot inside and outside canopy of each chosen tree were collected. Samples from every 10 individuals were pooled together as a replicate group. Leaves damaged by insects and disease or mechanical factors were avoided. About of 50-100 leaves in each group were collected to account for tree-to-tree variability in composition. The sampling work were carried out in March, June, September, and December of 2009. All samples were taken to the laboratory immediately after sampling and cleaned with distilled water.

\subsection{Methods}

All chemicals were of analytical reagent purity grade. An additional standard denoted here as purified tannin, was extracted from A. corniculatum leaves and purified on Sephadex LH-20 (Amersham, USA) according to the procedure previously described by Asquith and Butler (1986) as modified by Hagerman (2002). The condensed tannin standard was freeze-dried and stored at $-20{ }^{\circ} \mathrm{C}$ until required. Procedures described by Lin et al. (2006) were used to determine total phenolics (TP), extractable condensed tannins (ECT), protein-bound condensed tannins (PBCT), and fibre-bound condensed tannins (FBCT). TP were measured with the Prussian blue method (Graham, 1992), and ECT, PBCT and FBCT were assayed by the butanol-HCl method (Terrill et al., 1992) using purified tannins from $A$. corniculatum leaves as the standard. The contents of total condensed tannins (TCT) were calculated by adding the respective quantities of ECT, PBCT, and FBCT (Terrill et al., 1992). After digested with sulfuric acid and hydrogen peroxide, the $\mathrm{N}$ content of plant samples was determined by the micro Kjeldahl method (Yoshida et al., 1972) and the P content was assayed by the ascorbic acidantimony reducing phosphate colorimetric method (Nanjing Institute of Soil Science, 1978).

\subsection{Statistical Analyses}

All measurements were replicated three times and analyzed using one-way analysis of variance (ANOVA) (SPSS 16.0 for Windows) with TP, ECT, PBCT, FBCT and TCT. The Student-New-man-Keuls multiple comparison method was used to test significant differences between any two leaf characters.

\section{RESULTS}

\subsection{Seasnonal Dynamics of Total Phenolics Contents}

No significant differences were found for TP content of sun leaves among four seasons. It ranged from $285.21 \mathrm{mg} / \mathrm{g}$ \pm 16.90 in autumn to $318.68 \pm 9.47 \mathrm{mg} / \mathrm{g}$ in spring. For shade leaves, the lowest TP content occurred in summer $[(159.94 \pm 9.73) \mathrm{mg} / \mathrm{g}]$ and the highest TP content occurred in autumn $[(245.43 \pm 11.17) \mathrm{mg} / \mathrm{g}]$ and winter $[(230.12 \pm$ $12.22) \mathrm{mg} / \mathrm{g}](\mathrm{P}<0.05)$. TP content of sun leaves were significantly higher than the shade ones through all seasons $(\mathrm{P}<0.05)$ (Fig. 1).

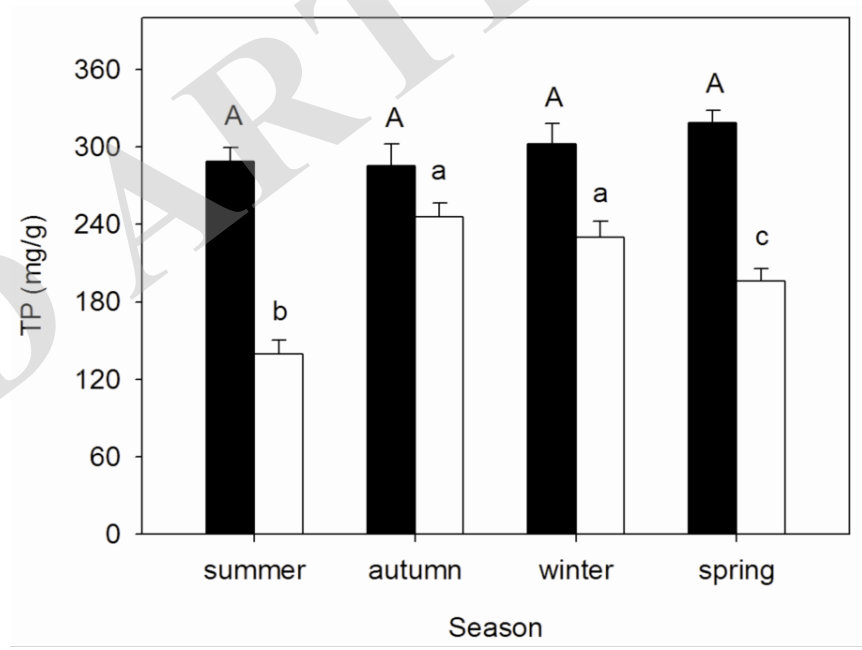

Fig. (1). Seasonal changes in total phenolics (TP) contents in the leaves of A. corniculatum. Symbols are black bars for sun leaves and white bars for shade leaves. Different letters show significant differences from each other at $P<0.05$.

\subsection{Seasonal Dynamics of Condensed Tannin Contents}

ECT contents of sun leaves in summer and spring were $288.82 \pm 7.24 \mathrm{mg} / \mathrm{g}$ and $291.74 \pm 17.10 \mathrm{mg} / \mathrm{g}$, respectively. The values in these two seasons were significantly higher than that in the other two seasons. The ECT contents of shade leaves showed highest values in autumn (140.25 \pm $10.33 \mathrm{mg} / \mathrm{g})$ and winter $(135.38 \pm 12.59 \mathrm{mg} / \mathrm{g})$, which were significantly different from the observation of ECT contents of sun leaves. The ECT contents of sun leaves in all seasons were significantly higher than those in shade leaves $(\mathrm{P}<$ 0.05) (Fig. 2A).

The PBCT contents of sun leaves fluctuated between $5.15 \pm 0.55 \mathrm{mg} / \mathrm{g}$ and $11.53 \pm 0.84 \mathrm{mg} / \mathrm{g}$, and the values in 
autumn and winter were significantly higher than those in summer and spring $(\mathrm{P}<0.05)$. The PBCT contents of shade leaves exhibited significant differences among different seasons, while highest in autumn $10.54 \pm 0.8492 \mathrm{mg} / \mathrm{g}$, and lowest in summer $4.40 \pm 0.59 \mathrm{mg} / \mathrm{g}$. PBCT contents of sun leaves were significantly higher than those of shade leaves except for in spring (Fig. 2B).

The highest FBCT contents of sun leaves occurred in spring $(12.13 \pm 0.54 \mathrm{mg} / \mathrm{g})$, followed by autumn $(10.26 \pm$ $0.78 \mathrm{mg} / \mathrm{g})$, but no significant difference were observed between summer $(7.56 \pm 0.27 \mathrm{mg} / \mathrm{g})$ and winter $(8.57 \pm 0.94$ $\mathrm{mg} / \mathrm{g}$ ). The FBCT contents of shade leaves were lower in summer than that in other seasons. Except for in summer, FBCT content of sun leaves were significantly lower than those of shade ones (Fig. 2C). TCT contents of sun and shade leaves ranged from $200.19 \pm 10.33 \mathrm{mg} / \mathrm{g}$ to $309.48 \pm$ $17.26 \mathrm{mg} / \mathrm{g}$ and from $84.49 \pm 3.39 \mathrm{mg} / \mathrm{g}$ to $162.51 \pm 11.25$ $\mathrm{mg} / \mathrm{g}$, respectively. TCT and ECT contents showed the same trends during the growing seasons, and the TCT contents of sun leaves were significantly higher than those of shade ones in the same seasons $(\mathrm{P}<0.05)$ (Fig. 2D).

\subsection{Seasonal Dynamics of the $N$ And $P$ Content and N:P Ratios}

The sun leaves had significantly higher nitrogen contents in winter and autumn than those in spring and summer, while the shade ones had significantly higher nitrogen contents in winter and summer than in autumn and spring (Fig. 3A).

(A)

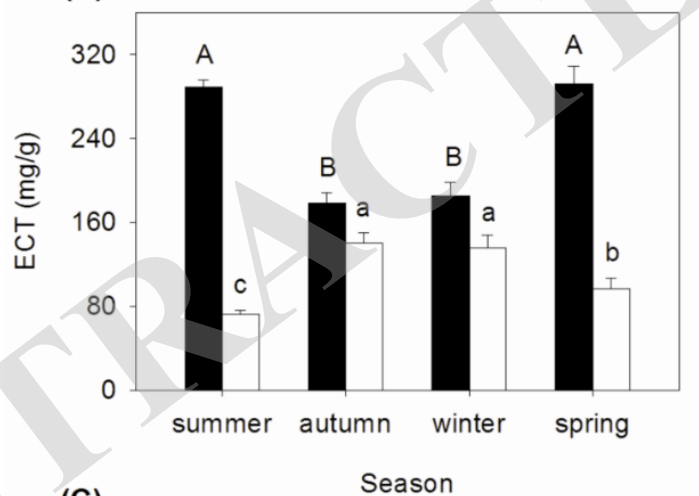

(C)

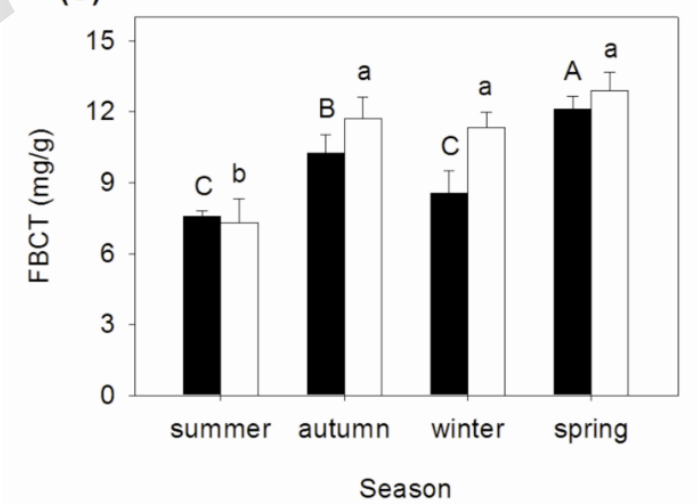

The $\mathrm{P}$ contents of sun leaves were highest in winter $(2.62$ $\pm 0.11 \mathrm{mg} / \mathrm{g})$ and lowest in summer $(1.06 \pm 0.07 \mathrm{mg} / \mathrm{g})$. The shade leaves showed highest $\mathrm{P}$ content in winter $(3.45 \pm 0.20$ $\mathrm{mg} / \mathrm{g})$ and lowest $\mathrm{P}$ content in spring $(1.16 \pm 0.03 \mathrm{mg} / \mathrm{g})$. Except for in autumn and spring, the $\mathrm{P}$ content of shade leaves were significantly higher than those of sun ones in summer and winter (Fig. 3B).

$\mathrm{N}: \mathrm{P}$ ratios of sun and shade leaves ranged from $8.15 \pm$ $0.65 \mathrm{mg} / \mathrm{g}$ to $13.22 \pm 0.53 \mathrm{mg} / \mathrm{g}$ and from $6.39 \pm 0.35 \mathrm{mg} / \mathrm{g}$ to $13.41 \pm 0.25 \mathrm{mg} / \mathrm{g}$. All values were below 14 and showed the same trends during the growing seasons, which highest in spring and lowest in winter. Except for in spring, the $\mathrm{N}: \mathrm{P}$ ratios of sun leaves were significantly higher than those of shade ones in other seasons (Fig. 4).

\subsection{Seasnonal Dynamics of TP:N and TCT: $N$ Ratios}

Except for autumn, the TP:N ratios of sun leaves were significantly higher than those of shade ones in the other seasons. The TP:N ratios of sun leaves were significantly higher in summer $(22.60 \pm 0.59 \mathrm{mg} / \mathrm{g})$ and spring $(19.28 \pm$ $0.63 \mathrm{mg} / \mathrm{g})$ than those in autumn $(13.79 \pm 0.99 \mathrm{mg} / \mathrm{g})$ and winter $(14.19 \pm 0.10 \mathrm{mg} / \mathrm{g})$. TP:N ratios of shade leaves were significant different in different seasons, which was highest in autumn $(15.31 \pm 0.34 \mathrm{mg} / \mathrm{g})$, and lowest in summer $(7.82$ $\pm 0.82 \mathrm{mg} / \mathrm{g}$ ) (Fig. 5A).

TCT:N and TP:N ratios of sun leaves showed the same trends during the growing seasons, which was highest in

\section{(B)}
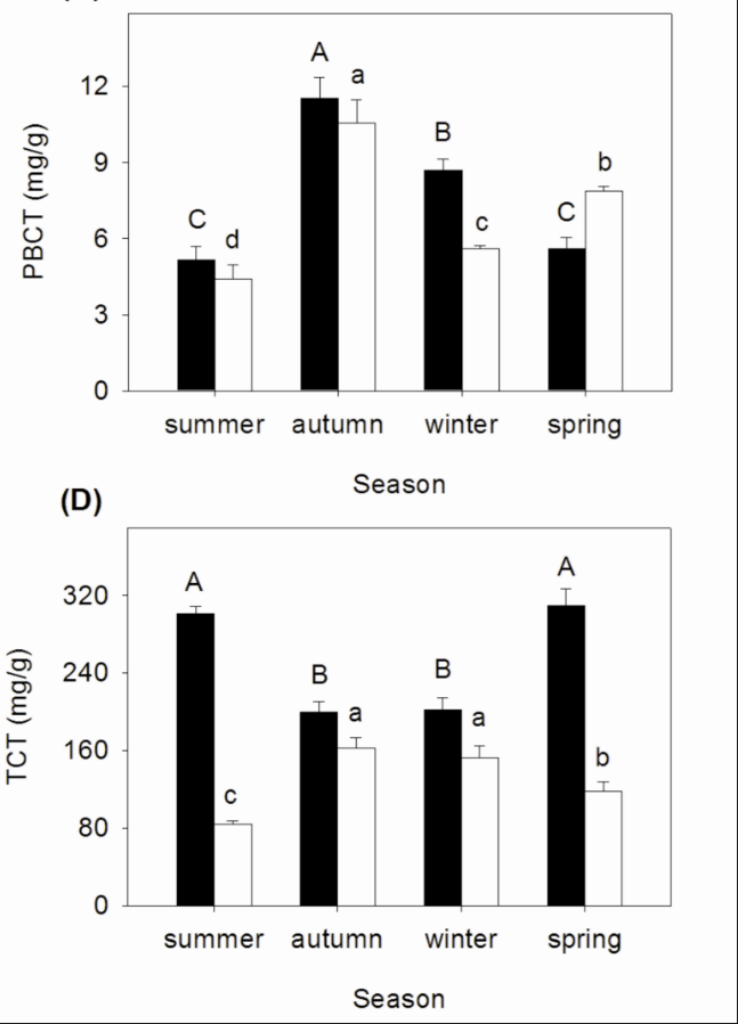

Fig. (2). Seasonal changes in ECT, PBCT, FBCT and TCT contents in the leaves of $A$. corniculatum. Symbols are black bars for sun leaves and white bars for shade leaves. Different letters show significant differences from each other at $P<0.05$. 

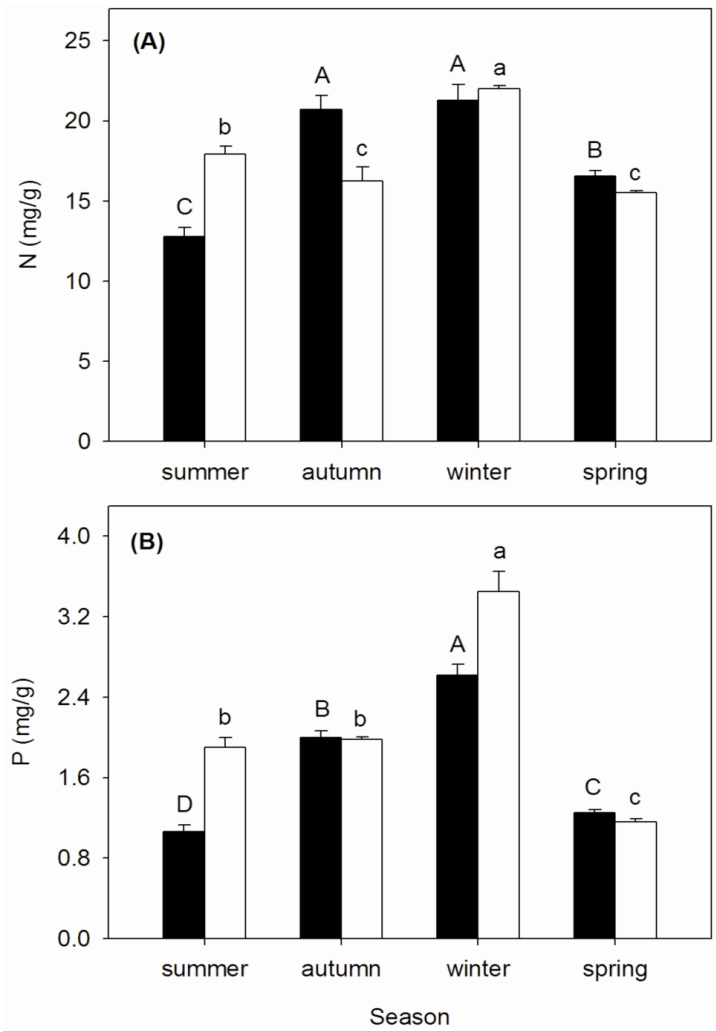

Fig. (3). Seasonal changes in the $\mathrm{N}$ and $\mathrm{P}$ contents in the leaves of A. corniculatum. Symbols are black bars for sun leaves and white bars for shade leaves. Different letters show significant differences from each other at $P<0.05$.

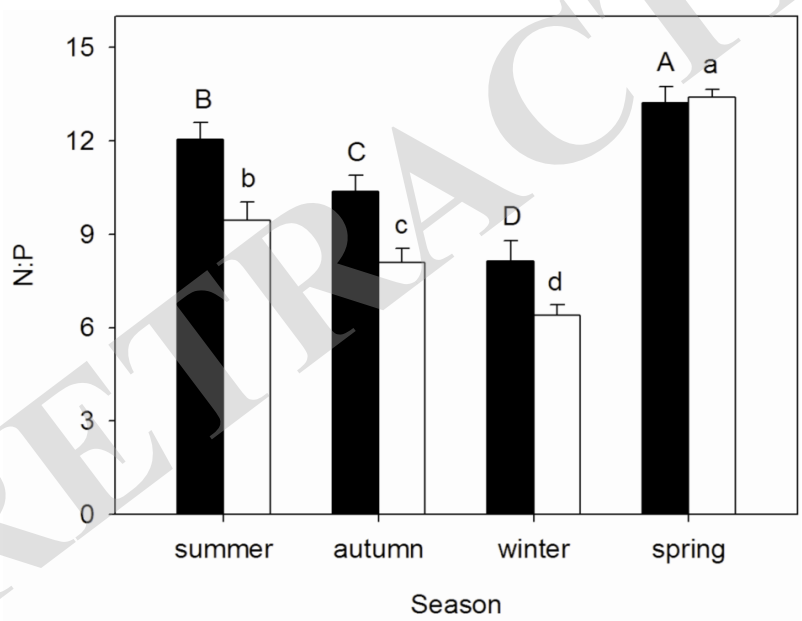

Fig. (4). Seasonal changes of $\mathrm{N}: \mathrm{P}$ ratios in the leaves of $A$. corniculatum. Symbols are black bars for sun leaves and white bars for shade leaves. Different letters show significant differences from each other at $P<0.05$.

summer and lowest in autumn and winter. But TCT:N and TP:N ratios of shade leaves showed another trends during the growing seasons, both highest in autumn $(8.74 \pm 0.36$ $\mathrm{mg} / \mathrm{g})$ and lowest in summer $(4.07 \pm 0.30 \mathrm{mg} / \mathrm{g})$ (Fig. 5B).
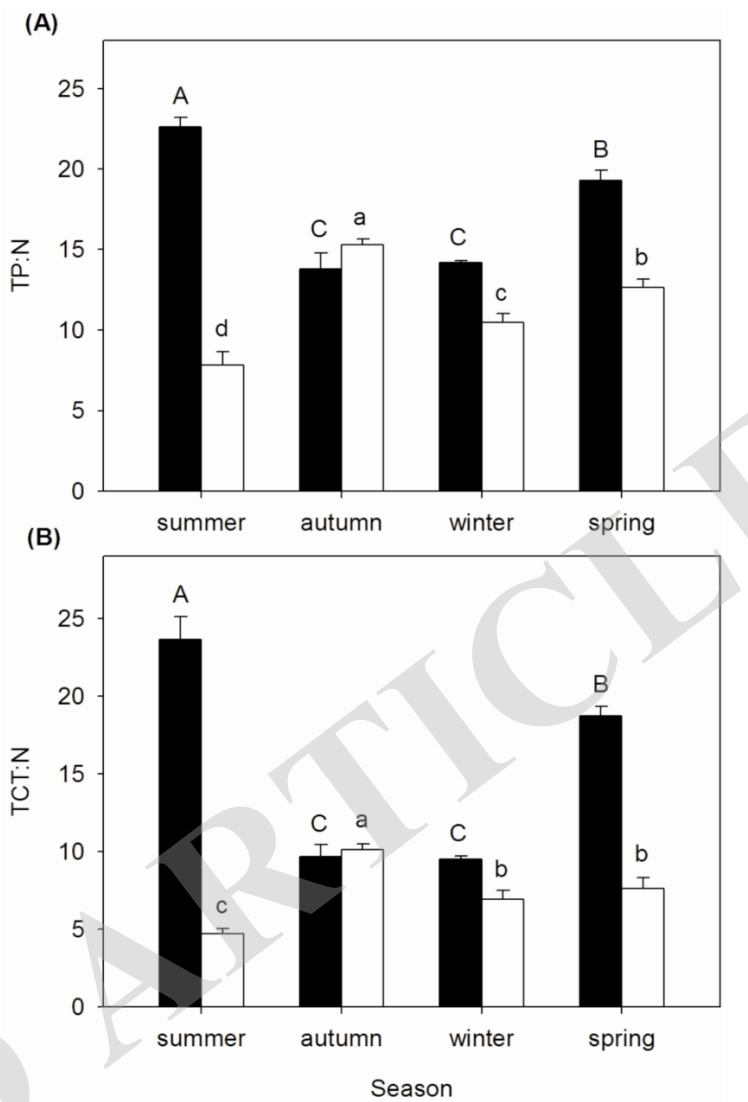

Fig. (5). Seasonal changes of TP:N and TCT:N ratios in the leaves of $A$. corniculatum. Symbols are black bars for sun leaves and white bars for shade leaves. Different letters show significant differences from each other at $P<0.05$.

\section{DISCUSSION}

Light is one of the most important factors affecting the growth of plants and its intensity played important role in the formation and accumulation of secondary metabolites in plants [16]. In this study, sun leaves had higher contents of TP (Fig. 1A) and ECT (Fig. 2A) than the shade, indicating that the light intensity stimulate the synthesis of tannin in the plant. This result is consistent with the photodamage hypothesis proposed by Close and McArthu [22]. When the energy exceeded photosynthesis capacity, this excess energy absorbed by leaves might increase concentration of reactive oxygen species in plants and lead to destructive oxidation processes, such as lipid peroxidation, destruction of chlorophyll, oxidation of proteins, damage of nucleic acid $[23,24]$ and Calvin cycle enzymes [25]. In order to reduce the damage of oxidative caused by excess energy, plants will inevitably synthesis more antioxidant substances such as polyphenols to protect themselves from being impacted by phytodamage. Polyphenols are known as "UV filters" which has a strong ability to absorb ultraviolet light [15]. Many studies reported that the phenolics content in sun leaves are significantly higher than that in the shade leaves [26, 27]. Sun leaves suffered from much stronger ultraviolet radiation 
than the shade leaves, hence the much higher phenolics in sun leaves can reduce ultraviolet harm to the plant itself.

Seasonal variation of chemicals in the leaves could reflect the requirement of carbohydrate and nutrient during the growth and differentiation of plant [28]. Carbon Nitrogen Balance Hypothesis (CNB) considered that the synthesis of carbon-rich secondary metabolites was influenced by the synthesis of photosynthesis carbohydrate [29]. If the plant had strong photosynthesis capacity, the carbohydrates not only meet the needs of their own growth and development, the remaining carbon also could be used for the synthesis of carbon-based secondary metabolites such as tannins. On the contrary, if the photosynthetic level of the plant is too limited to be only able to meet their growth and development, the carbon assigned to secondary metabolites will reduce. According to this theory, it can be assumed that the content of carbon-based secondary metabolites tannins in the summer should be higher than that in the other seasons due to the stronger photosynthesis. In this study, soluble condensed tannin content in the sun leaves of $A$. corniculatum was highest in summer (Fig. 2A). The FBCT content of sun leaves of $A$. corniculatum in summer was higher than that in shade leaves in any seasons except in spring (Fig. 2B), while the sun leaves had lower FBCT content than shade leaves except in summer (Fig. 2C). All the results were consistent with our above assumption.

Generally, the nutrient supply of the plant could be reflect from the content of leaf nutrient and they are affected by season, tree nutrition balance and other factors [30, 31]. Our results showed that sun leaves had higher leaf nitrogen (N) content than the shade leaves in the autumn, but lower in summer and no significant difference $(\mathrm{P}>0.05)$ between winter and spring. This indicated the effects of light intensity on the $\mathrm{N}$ content of leaves varied among different seasons. Significant difference of the $\mathrm{P}$ content in sun leaves of $A$. corniculatum were found among different seasons, while the highest values occurred in winter and lowest values were found in summer (Fig. 3B). The accumulation of nutrients in winter might be attributed to the resistance to low temperature [32]. The $\mathrm{P}$ content in sun leaves was lower than that of shade leaves in summer and winter, but no significant differences were found between them in spring and autumn.

In most ecosystems, nitrogen and phosphorus are important factors affecting plant growth and as well as an important factor influencing the community primary productivity [20, 33]. According to Güsewell and Koerselman [21] and Rejmankova [34], the N: P ratio in mature leaf can be used to indicate the nutrient limitation status of the community. It represents phosphorus limit when $\mathrm{N}: \mathrm{P}$ ratio is higher than 16 and it was nitrogen limit when $\mathrm{N}: \mathrm{P}$ ratio below 14 . We found that leaf $\mathrm{N}: \mathrm{P}$ of $A$. corniculatum in sun leaves and shade leaves in different seasons ranged between $8.15 \pm 0.65 \sim 13.22 \pm 0.53$ and 6.39 $\pm 0.35 \sim 13.41 \pm 0.25$, respectively. All $\mathrm{N}: \mathrm{P}$ ratios were less than 14, indicating that the habitat conditions of $A$. corniculatum are $\mathrm{N}$ limit. Meanwhile, similar trends of seasonal variation were found for leaf $\mathrm{N}$ : $\mathrm{P}$ ratio of $A$. corniculatum in sun leaves and shade leaves. Both of them showed lowest N:P ratios in winter, which might be related to the growth of new leaves. It required a lot of the nutrients for the growth of new leaves in winter, which caused stronger nitrogen limitation.

In addition, correlation analysis showed that no significant relationship were found between the nitrogen content and total phenol content $(\mathrm{F}=0.033, \mathrm{R}=0.039, \mathrm{P}=$ 0.858 ) and between total nitrogen content and condensed tannin content $(\mathrm{F}=2.373, \mathrm{R}=0.312, \mathrm{P}=0.138)$. Hence, there are no correlation between tannin content and leaf protein content which does not meet the competition model (Protein Competition Model, PCM) [35]. The model assumes that both the synthesis of condensed tannin such as Phenylpropanoids and their derivatives and the synthesis of protein requires a large amount of phenylalanine as a precursor. When the plant grew in an appropriate habitat, it will consume plenty of phenylalanine for protein synthesis to satisfy the growth and development of plants, resulting in the lack of phenylalanine needed for the synthesis of condensed tannins and the reduction of condensed tannins content. In contrast, the growth of plant will be limited when it was in a poor habitat. Under this circumstance, the amount of protein required for the growth of plant is reduced and a large number of extra phenylalanine could be used synthesis of condensed tannins, resulting in a significant increase in condensed tannin content. Consequently, significantly negative correlation existed between the content of protein and condensed tannin.

Generally, the contents of tannins and nutrient in plant tissue had opposite trend, thus the TP: $\mathrm{N}$ and ECT: $\mathrm{N}$ ratio could be used to indicate the health quality of the leaves [36]. In this study, TP: $\mathrm{N}$ and ECT: $\mathrm{N}$ in the sun leaves were significantly higher than that in shade leaves except for autumn (Fig. 5). The sun leaves, which at the outside part of the canopy, are more easily grazed by herbivores. Without physical or mechanical defense, a chemical defense by producing more secondary metabolites tannin were developed to protect the leaves from herbivores.

\section{CONCLUSION}

The content of tannin in leaves of Aegiceras corniculatum is significantly influnced by light intensity. In all four seasons, the contents of TP, ECT and TCT in the sun leaves were significantly higher than those in the shade leaves. The high tannin content of sun leaves can reduce the oxidative damage phytodamage caused by the excess light energy.

(2) The N: P ration in the leaves of A. corniculatum in sun leaves and shade leaves ranged between $8.15 \pm$ $0.65 \sim 13.22 \pm 0.53 \mathrm{mg} / \mathrm{g}$ and $6.39 \pm 0.35 \sim 13.41 \pm$ $0.25 \mathrm{mg} / \mathrm{g}$, respectively. The ratio of these two kind of leaves both were lower than 14, indicating that the habitat of the Aegiceras corniculatum in our study are $\mathrm{N}$ limited. 
(3) TP: $\mathrm{N}$ ratio and ECT: $\mathrm{N}$ ratio in the sun leaves of Aegiceras corniculatum were significantly higher than those in the shade leaves in all seasons except for autumn. The high TP: $\mathrm{N}$ ratio and ECT: $\mathrm{N}$ ratio in the sun leaves helped to improve the ability for plants to resist pests and diseases.

\section{CONFLICT OF INTEREST}

The author confirms that this article content has no conflict of interest.

\section{ACKNOWLEDGEMENTS}

Declared none.

\section{REFERENCES}

[1] Y. M. Lin, J. W. Liu, P. Xiang, P. Lin, Z. H. Ding, and L. d. S. L. Sternberg, "Tannins and nitrogen dynamics in mangrove leaves at different age and decay stages (Jiulong River Estuary, China)", Hydrobiologia, vol. 583, no. 1, pp. 285-295, 2007.

[2] P. J. Hernes, and J. I. Hedges, "Determination of condensed tannin monomers in environmental samples by capillary gas chromatography of acid depolymerization extracts", Analytical Chemistry, vol. 72, no. 20, pp. 5115-5124, 2000.

[3] T. Kraus, Z. Yu, C. Preston, R. Dahlgren, and R. Zasoski, "Linking chemical reactivity and protein precipitation to structural characteristics of foliar tannins", Journal of Chemical Ecology, vol. 29 , no. 3, pp. 703-730, 2003.

[4] R. G. Cates, and D. F. Rhoades, "Patterns in the production of antiherbivore chemical defenses in plant communities", Biochemical Systematics And Ecology, vol. 5, no. 3, pp. 185-193, 1977.

[5] W. V. Zucker, "Tannins: does structure determine function? An ecological perspective", American Naturalist, vol. 121, no. 3, pp. 335-365, 1983.

[6] J. D. Hofland-Zijlstra, and F. Berendse, "The effect of nutrient supply and light intensity on tannins and mycorrhizal colonisation in Dutch heathland ecosystems", Plant Ecology, vol. 201, no. 2, pp. 661-675, 2009.

[7] D. M. Alongi, "Present state and future of the world's mangrove forests", Environmental Conservation, vol. 29, no. 3, pp. 331-349, 2002.

[8] S. Bouillon, R. M. Connolly, and S. Y. Lee, "Organic matter exchange and cycling in mangrove ecosystems: Recent insights from stable isotope studies", Journal of Sea Research, vol. 59, no. 1-2, pp. 44-58, 2008.

[9] E. Kristensen, "Mangrove crabs as ecosystem engineers: with emphasis on sediment processes", Journal of Sea Research, vol. 59, no. $1-2$, pp. 30-43, 2008

[10] D. Alongi, "The influence of mangrove-derived tannins on intertidal meiobenthos in tropical estuaries", Oecologia, vol. 71, no. 4, pp. 537-540, 1987.

[11] F. Covelo, and A. Gallardo, "Temporal variation in total leaf phenolics concentration of Quercus robur in forested and harvested stands in northwestern Spain", Canadian Journal of Botany, vol. 79, no. 11, pp. 1262-1269, 2001.

[12] A. Gallardo, and J. Merino, "Nitrogen immobilization in leaf litter at two Mediterranean ecosystems of SW Spain", Biogeochemistry, vol. 15, no. 3, pp. 213-228, 1992.

[13] R. R. Northup, Z. Yu, R. A. Dahlgren, and K. A. Vogt, "Polyphenol control of nitrogen release from pine litter", Nature, vol. 377 , no. 6546 , pp. 227-229, 1995.

[14] L. Serrano, "Leaching from vegetation of soluble polyphenolic compounds, and their abundance in temporary ponds in the Doñana National Park (SW Spain)", In: Dissolved Organic Matter in Lacustrine Ecosystems, Springer, pp. 43-50, 1992.

[15] Y. Lin, P. Xiang, and P. Lin, "Studies on tannins of mangroves-a review", Mar. Sci, vol. 29, pp. 59-63, 2005.
[16] D. Treutter, "Significance of flavonoids in plant resistance and enhancement of their biosynthesis", Plant Biology, vol. 7, no. 6, pp. 581-591, 2005.

[17] I.C. Feller, "Effects of nutrient enrichment on growth and herbivory of dwarf red mangrove (Rhizophora mangle)", Ecological monographs, pp. 477-505, 1995.

[18] G. Lin, and L. D. S Sternberg, "Effect of growth form, salinity, nutrient and sulfide on photosynthesis, carbon isotope discrimination and growth of red mangrove (Rhizophora mangle L.)", Functional Plant Biology, vol. 19, no. 5, pp. 509-517, 1992.

[19] K. L. McKee, I. C. Feller, M. Popp, and W. Wanek, "Mangrove isotopic $\left(\delta^{15} \mathrm{~N}\right.$ and $\left.\delta{ }^{13} \mathrm{C}\right)$ fractionation across a nitrogen $v s$ phosphorus limitation gradient", Ecology, vol. 83, no. 4, pp. 10651075, 2002.

[20] S. Güsewell, "N: P ratios in terrestrial plants: variation and functional significance", New Phytologist, vol. 164, no. 2, pp. 243266, 2004.

[21] S. Güsewell, and W. Koerselman, "Variation in nitrogen and phosphorus concentrations of wetland plants", Perspectives in Plant Ecology, Evolution and Systematics, vol. 5, no. 1, pp. 37-61, 2002.

[22] D. C. Close, and C. McArthur, "Rethinking the role of many plant phenolics-protection from photodamage not herbivores?", Oikos, vol. 99, no. 1, pp. 166-172, 2002.

[23] J. P. Knox, and A. D. Dodge, "Singlet oxygen and plants", Phytochemistry, vol. 24, no. 5, pp. 889-896, 1985.

[24] J. G. Scandalios, "Oxygen stress and superoxide dismutases", Plant Physiology, vol. 101, no. 1, pp. 7, 1993.

[25] W. M. Kaiser, "Reversible inhibition of the Calvin cycle and activation of oxidative pentose phosphate cycle in isolated intact chloroplasts by hydrogen peroxide", Planta, vol. 145, no. 4, pp. 377-382, 1979.

[26] D. C. Close, N. W. Davies, and C. L. Beadle, "Temporal variation of tannins (galloylglucoses), flavonols and anthocyanins in leaves of Eucalyptus nitens seedlings: implications for light attenuation and antioxidant activities", Functional Plant Biology, vol. 28, no. 4, pp. 269-278, 2001.

[27] T. Swain, and W. Hillis, "The phenolic constituents of Prunus domestica. I.-The quantitative analysis of phenolic constituents", Journal of the Science of Food and Agriculture, vol. 10, no. 1, pp. 63-68, 1959.

[28] J. Moorby, and P. Wareing, "Ageing in woody plants", Annals of Botany, vol. 27, no. 2, pp. 291-308, 1963.

[29] J. P. Bryant, F. S. Chapin III, and D. R. Klein, "Carbon/nutrient balance of boreal plants in relation to vertebrate herbivory", Oikos, vol. 40 , no. 3 , pp. $357-368,1983$,

[30] M. R. Walbridge, "Phosphorus availability in acid organic soils of the lower North Carolina coastal plain", Ecology, vol. 72, pp. 20832100, 1991.

[31] W. Wang, and P. Lin, "Comparative study on seasonal changes in element concentrations in leaves of Kandelia candel and Rhizophoras stylosa at Jiulongjiang estuary", Acta Ecologica Sinica, vol. 21, no. 8, pp. 1233-1238, 2000.

[32] W. Wang, and Q. Ye, X. Wang, and P. Lin, "Impact of substrate salinity on caloric value, energy accumulation and its distribution in various organs of Bruguiera gymnorrhiza seedlings", The Journal Of Applied Ecology, vol. 12, no. 1, pp. 8-12, 2001.

[33] M. F. Knecht, and A. Göransson, "Terrestrial plants require nutrients in similar proportions", Tree Physiology, vol. 24, no. 4, pp. 447-460, 2004.

[34] E. Rejmánková, "Nutrient resorption in wetland macrophytes: comparison across several regions of different nutrient status", New Phytologist, vol. 167, no. 2, pp. 471-482, 2005.

[35] C. G. Jones, and S. E. Hartley, "A protein competition model of phenolic allocation", Oikos, vol. 86, no. 1, pp. 27-44, 1999.

[36] L. H. Zhang, Y. M. Lin, and G. Ye, "Effects of Nutrients and Acidity on Tannin Production of Casuarina equisetifolia Seedling Branchlets", Scientia Silvae Sinicae, vol. 2, pp. 1-13, 2011.

Received: May 26, 2015

Revised: July 14, 2015

Accepted: August 10, 2015

(C) Huang et al.; Licensee Bentham Open.

This is an open access article licensed under the terms of the Creative Commons Attribution Non-Commercial License (http://creativecommons.org/licenses/by$\mathrm{nc} / 3.0 /$ ) which permits unrestricted, non-commercial use, distribution and reproduction in any medium, provided the work is properly cited. 